\title{
The Constitutional STRENGTH OF Indiana's Medical ReView Panel Process: How to OVercome THE INEVITABLE CHALLENGES
}

\author{
ANNA KARAS* \\ I. INTRODUCTION \\ Beginning in the $1970 \mathrm{~s}$, states started implementing medical review panels, \\ also known as screening panels, in response to a medical malpractice crisis. ${ }^{1} \mathrm{~A}$ \\ rise in medical malpractice claims resulted in an increase in the cost of medical \\ malpractice insurance. ${ }^{2}$ So much so, that in some states, the high cost of \\ malpractice insurance was said to be driving certain specialties of doctors to leave \\ the state due to the high risk of a lawsuit. ${ }^{3}$ Arizona was the first state to \\ implement medical review panels in 1976 with the goal of having a group of \\ health care professionals evaluate medical malpractice cases before they were \\ filed in court. ${ }^{4}$ The hope was that the panels would create a more time and cost- \\ efficient way to resolve these disputes. ${ }^{5}$ Since Arizona's implementation of \\ medical review panels, at least seventeen states, including Indiana, have created \\ similar screening panels. ${ }^{6}$ \\ Medical review panels have been constitutionally challenged on various \\ grounds from their inception. ${ }^{7}$ These challenges have involved arguments based \\ on equal protection, due process, separation of powers, right to a jury trial, and \\ openness to the courts. ${ }^{8}$ While states such as Indiana have upheld their medical \\ review panel processes, ${ }^{9}$ similar statutes in other states have been held to be \\ unconstitutional. ${ }^{10}$ \\ Medical review panels are only one mode of tort reform that is reshaping \\ * J.D. Candidate, 2021, Indiana University Robert H. McKinney School of Law; B.A., \\ 2017, Purdue University. \\ 1. Jean Macchiaroli Eggen, Medical Malpractice Screening Panels: An Update and \\ Assessment, 6 J. HeAlth \& LifE SCI. L. 1, 3 (2013). \\ 2. $I d$. \\ 3. John Gregory, Medical Review Panels for Malpractice Claims, KET (Feb. 6, 2017), \\ https://www.ket.org/public-affairs/medical-review-panels/ [https://perma.cc/R4ZD-U4C8]. \\ 4. Courtney A. Simpkins \& Joseph L. Fink III, MRPs Are Both a Blessing and a Curse, \\ PhARMACY Times (Sept. 25, 2019), https://www.pharmacytimes.com/publications/issue/2019/ \\ september2019/mrps-are-both-a-blessing-and-a-curse [https://perma.cc/9XJT-8DE6]. \\ 5. $I d$. \\ 6. Id. \\ 7. Andrew Wilhoit, Improper Means to a Kalopsian End: An Analysis of Medical Review \\ Panels Under Kentucky's Constitution, 57 U. LouisviLLE L. REv. 439, 439 (2019). \\ 8. Id. \\ 9. See generally James D. Kemper et al., Reform Revisited: A Review of the Indiana Medical \\ Malpractice Act Ten Years Later, 19 IND. L. REV. 1129 (1986). \\ 10. Wilhoit, supra note 7.
}


medical malpractice litigation across the country. ${ }^{11}$ The review panels were introduced with many goals in mind, but how well the panels have met and are currently meeting those goals is questioned. ${ }^{12}$ These circumstances, and the constitutional claims brought across the country that are revealing a divide among states on how to respond, present an opportunity to revisit the Indiana Medical Malpractice Act. A look into the Indiana Medical Malpractice Act with this foresight may uncover areas in it that can be improved or modified to ensure it remains in effect through future challenges.

The first part of this Note discusses the history of Indiana's Medical Malpractice Act and the current format of medical review panels. The second part presents a discussion of the recent Kentucky Supreme Court decision that held the State's medical review panel statute unconstitutional. Third, this Note compares the Indiana Supreme Court's view of medical review panels to that of Kentucky's, followed by a discussion of whether the goals of medical review panels are being met. Next, this Note inquires why medical review panels cause such a delay in the system and whether there is still a medical malpractice crisis in the country. Lastly, alternatives to medical review panels are discussed, followed by suggestions to make the proceedings of a medical malpractice case more efficient.

\section{INDIANA’s MEDICAL MALPRACTICE ACT}

\section{A. General History}

In the 1970s, Indiana began looking at ways to fix the health care system that was "on the verge of a crisis." 13 Indiana's governor at the time, Governor Otis R. Bowen, was a medical doctor himself. ${ }^{14}$ Governor Bowen saw the need for changes in the medical malpractice system in Indiana and requested the legislature to evaluate the same. ${ }^{15}$ The Indiana Medical Malpractice Study Commission ("Commission") was created to study medical malpractice adjudication in Indiana and how residents of Indiana were affected by the current statutory scheme. ${ }^{16}$ The Commission published its findings for 1975 to 1976 , concluding there had been a $410 \%$ increase in the average medical malpractice insurance premiums for physicians from 1970 to $1975 .{ }^{17}$ There had also been a $42 \%$ increase in the frequency of claims filed against physicians in Indiana, and

11. Lydia Nussbaum, Trial and Error: Legislating ADR for Medical Malpractice Reform, 76 MD. L. REV. 247, 271-72 (2017).

12. See Eggen, supra note 1, at 3-4; see also Nussbaum, supra note 11, at 271.

13. Otis R. Bowen, Medical Malpractice Law in Indiana, 11 J. Legis. 15, 15 (1984).

14. Ashley Bullock Green, No "New" Breaches: Adding a Section to the Indiana Medical Malpractice Act to Alleviate the Pain Caused by K.D. v. Chambers, 49 VAL. U. L. REV. 955, 959 (2015).

15. Id. at 960 .

16. Bowen, supra note 13 , at 15 n.1.

17. Id. at 15 . 
the average damage award had increased from $\$ 12,993$ in 1970 to $\$ 34,297$ in $1975 .{ }^{18}$ Further, the Commission uncovered a practice that greatly affected Hoosiers: $65 \%$ of physicians in Indiana admitted having ordered procedures for patients that they considered "superfluous" due to a fear of being sued. ${ }^{19}$

The Commission also examined the various reasons for the increase in medical malpractice claims. ${ }^{20}$ The Commission found that patients were "more aware of medical malpractice and the legal redress available to them." 21 Additionally, patients had a greater expectation that a cure or better outcome would be obtained, which led to increased disappointment if the same did not occur. $^{22}$ There was also a finding of "increasing deterioration of the rapport between doctors and patients," which likely led to an increased number of claims. ${ }^{23}$ The Commission reported that physicians were not only significantly affected by the increase in malpractice claims but also by the increased cost of malpractice insurance. ${ }^{24}$ The heightened expense for malpractice insurance reportedly caused some physicians to practice with inadequate coverage or forego insurance altogether. ${ }^{25}$ This was especially true for physicians in high-risk specialties, such as surgeons and obstetrician-gynecologists ${ }^{26}$ patients tend to expect more from specialists, and they do not have the same close relationship with specialists as compared to their family doctors. ${ }^{27}$

In response to the Commission's findings, the Indiana General Assembly enacted Indiana's Medical Malpractice Act (“Act”) in 1975. ${ }^{28}$ Among the provisions, the Act capped the total amount of damages plaintiffs could recover, while also creating the review panel process to screen medical malpractice claims prior to being filed in state court. ${ }^{29}$

\section{B. Medical Review Panels}

An important aspect of the Medical Malpractice Act was the introduction of medical review panels. Medical review panels were implemented to review "all

18. Id.

19. Id.

20. See id. at 16 .

21. Id.

22. Id.

23. Id.

24. Id.

25. Id.

26. The Doctors Most Likely to Hear, 'We'll See You in Court,' ADVISORY BOARD (Nov. 17, 2017) http://www.advisory.com/daily-briefing/2017/11/17/medscape-malpractice [https://perma.cc/GA8N-QXQB].

27. Bowen, supra note 13, at 16.

28. Kemper et al., supra note 9, at 1129.

29. Id. at 1130 . 
proposed malpractice complaints." ${ }^{30}$ The purpose of these panels is to review the evidence of both parties and provide an opinion as to whether or not the case is one of malpractice. ${ }^{31}$

Medical review panels in Indiana consist of three health care providers and one non-voting attorney chairman. ${ }^{32}$ Once the attorney chairman is chosen either by agreement of the parties or striking panels, the parties begin to select health care providers to be on the panel. ${ }^{33}$ When there are one plaintiff and one named defendant, each party selects one health care provider, and the first two members chosen will select the third panelist. ${ }^{34}$ The first two panelists are either nominated by the parties, or the parties individually choose a specialty, and then striking panels of candidates are distributed to select the members. ${ }^{35}$ By statute, if there is one individual defendant, at least two of the members of the medical review panel must be of the same specialty. ${ }^{36}$ When the case involves multiple defendants of various specialties, serious delays can arise because the parties often want to ensure that their respective specialty is represented on the threemember panel. ${ }^{37}$

The potential for delays does not stop there. If a party chooses to nominate a health care provider, the other side can challenge the selection without cause. ${ }^{38}$ The parties are given two opportunities to nominate physicians for the medical review panel. ${ }^{39}$ If both selections are challenged, the panel chairman creates a striking panel of three physicians and each side takes turns striking providers from the list until one remains. ${ }^{40}$ Parties have to conduct internal conflict checks and perform research on the candidates listed in the striking panels, and the defendants have to confer and agree as to a joint strike. With parties having to conduct conflict checks and research on the members listed in the striking panels, as well as defendants having to confer and agree as to a joint strike, the process of seating the medical review panel can take weeks or months. ${ }^{41}$

Once the panel is formed, the statute provides that the panel is to render its opinion within 180 days of selecting the final panel member. ${ }^{42}$ However, even with the 180-day deadline, the panel rarely gives its opinion within that time. ${ }^{43}$ This is due to various reasons, including the replacement of panel members,

30. Bowen, supra note 13, at 22 .

31. Id.

32. IND. CODE $\S 34-18-10-3(2020)$.

33. See IND. CODE $§ 34-18-10-6$ (2020).

34. Id.

35. See id.

36. IND. CODE § 34-18-10-8 (2020).

37. See IND. CODE $\S \S 34-18-10-7$ to -8 (2020).

38. IND. CODE $\S 34-18-10-10$ (2020).

39. Id.

40. Id.

41. See Eggen, supra note 1.

42. IND. CoDE § 34-18-10-13 (2020).

43. Kemper et al., supra note 9, at 1133. 
waiting on submissions from all parties, and finding a time to convene the panel that works for all panelists. ${ }^{44}$ After the panel members review all the materials provided to them and meet to discuss the evidence, the statute provides four opinions that they can reach:

(1) The evidence supports the conclusion that the defendant or defendants failed to comply with the appropriate standard of care as charged in the complaint.

(2) The evidence does not support the conclusion that the defendant or defendants failed to meet the applicable standard of care as charged in the complaint.

(3) There is a material issue of fact, not requiring expert opinion, bearing on liability for consideration by the court or jury.

(4) The conduct complained of was or was not a factor of the resultant damages. If so, whether the plaintiff suffered:

(A) any disability and the extent and duration of the disability; and

(B) any permanent impairment and the percentage of the impairment. ${ }^{45}$

After the panelists meet and form their opinion, the opinion is admissible evidence in court if the case proceeds to trial, but the opinion is not conclusive. ${ }^{46}$

\section{THE RECENT KENTUCKY SUPREME COURT DECISION: COMMONWEALTH V. CLAYCOMB}

In 2017, Kentucky enacted the Medical Review Panel Act, creating a medical review panel process. ${ }^{47}$ The Kentucky lawmakers modeled their review process after Indiana's, with a few minor changes. ${ }^{48}$ The Medical Review Panel Act gave the panel members nine months to issue an opinion as to whether or not the plaintiff had a valid claim. ${ }^{49}$ The law was quickly challenged by the parents of a young boy who was born with brain damage and cerebral palsy. ${ }^{50}$ The parents sued their family physician. ${ }^{51}$ They argued, among other things, that the panel

44. Id. at $1134 ; \S 34-18-10-13$.

45. IND. CODE $\S 34-18-10-22$ (2020).

46. IND. CoDE $\S 34-18-10-23$ (2020).

47. Tanya Albert Henry, Top Kentucky Court Strikes Down Law on Medical Review Panels, AMA (Dec. 10, 2018), https://www.ama-assn.org/health-care-advocacy/judicial-advocacy/topkentucky-court-strikes-down-law-medical-review-panels [https://perma.cc/5B6V-TXY5].

48. See Ky. Rev. Stat. Ann. ch. 216C (West repealed 2020).

49. Anjelica Cappellino, How Are Medical Malpractice Review Panels Impacting the Legal Process, EXPERT INST. (Aug. 30, 2018), https://www.theexpertinstitute.com/are-medicalmalpractice-review-panels-helping-or-hindering-the-legal-process/ [https://perma.cc/A8P5-PUSV].

50. Id.; Commonwealth v. Claycomb, 566 S.W.3d 202, 206 (Ky. 2018).

51. Cappellino, supra note 49. 
process created an unreasonable delay that violated the open courts guarantee under the Kentucky Constitution..$^{2}$ In a unanimous decision, the Supreme Court of Kentucky held that the Medical Review Panel Act were unconstitutional. ${ }^{53}$ The court reasoned that because the statute created a mandatory delay for individuals trying to file medical malpractice claims, the statute was in violation of Section 14 of the Kentucky Constitution. ${ }^{54}$ Section 14 provides that "[a]11 courts shall be open, and every person for an injury done him in his lands, goods, person or reputation, shall have remedy by due course of law, and right and justice administered without sale, denial or delay." 55

\section{ANALYSIS}

\section{A. Indiana's Constitutional Analysis of Medical Review Panels}

Although the Kentucky Medical Review Panel Act was modeled after Indiana's Medical Malpractice Act, the Supreme Court of Kentucky used a different constitutional analysis than the Supreme Court of Indiana when it reviewed the constitutionality of the Kentucky Act. In 1980, the constitutionality of Indiana's Medical Malpractice Act was challenged in the case of Johnson v. St. Vincent Hospital. ${ }^{56}$ In Johnson, the plaintiffs contended that the delay and expense in getting to a jury trial caused by the Act was unconstitutional based on both article I, section 20 and article I, section 12 of the Indiana Constitution. ${ }^{57}$

The court in Johnson first reasoned that the Act did not take away the right to a jury trial because the delay and cost that the Act imposed did "not alter or change and [did] not impair the right contrary to constitutional limitation." ${ }^{58}$ The court also explained that the requirement of plaintiffs submitting their case to a panel was a reasonable requirement meant to help the State manage the large amounts of malpractice claims it was facing. ${ }^{59}$ One justification for the delay offered by the court was that the panel process "generates evidence admissible at a future trial of the claim." ${ }^{60}$ Because delays are part of any case, the time spent producing evidence for the medical review panel "reduce[d] total aggregate time

52. Id.; Claycomb, 566 S.W.3d at 206.

53. Claycomb, 566 S.W.3d at 206.

54. Id. at 213; Henry, supra note 47.

55. KY. CONST. $§ 14$.

56. Johnson v. St. Vincent Hosp., 273 Ind. 374, 378 (1980).

57. Id. at 382-83, 386; see IND. CONST. art. I, $\S 20$ ("In all civil cases, the right of trial by jury shall remain inviolate"); see also IND. ConsT. art. I, § 12 ("All courts shall be open; and every person, for injury done to him in his person, property, or reputation, shall have remedy by due course of law. Justice shall be administered freely, and without purchase; completely, and without denial; speedily, and without delay.").

58. Johnson, 273 Ind. at 384.

59. Id.

60. Id. 
for trial preparation." ${ }^{61}$ Thus, the delay did not violate the right to a jury trial. ${ }^{62}$

As to the article I, section 12 claim, the court admitted there was a delay, even characterizing the restriction on accessing the courts as "severe." ${ }^{63}$ However, the court interpreted the Indiana Constitution to mean that if the delay was "reasonable in light of th[e] aim" to "preserve health care services," it would be constitutional. ${ }^{64}$ The court explained that an important goal of the Act was to "preserve health care services for the community." ${ }^{95}$ It concluded the delay would allow the medical review panel to form an expert opinion using their "knowledge and experience," as well as "encourage the mediation and settlement of claims and discourage the filing of unreasonably speculative lawsuits." ${ }^{" 66}$ The court noted that other Indiana laws also impose delays before a plaintiff can file a lawsuit, ${ }^{67}$ such as the requirement of "prepay[ing] court costs" or "proof of indigency at the time of filing suit." ${ }^{68}$ Although the Act does result in a delay to the plaintiffs' access to courts, the court found that the delay was reasonable and therefore upheld the Act as constitutional. ${ }^{69}$

\section{B. Kentucky's Constitutional Analysis of Medical Review Panels}

In Commonwealth v. Claycomb, the Supreme Court of Kentucky distinguished their case from Johnson in holding that Kentucky's medical review panels were unconstitutional. ${ }^{70}$ The Kentucky Court began its opinion by stating that, in their view, the "guarantee of a right of access to the courts" could be the most important right in state constitutions not otherwise included in the Bill of Rights. ${ }^{71}$ Although the provisions of the Indiana and Kentucky constitutions that were relevant to the challenges were almost identical, the Kentucky court disagreed with Indiana's analysis. ${ }^{72}$ The Kentucky Court stated that their open

61. Id.

62. Id.

63. Id. at 390 .

64. Id. at 384-90.

65. Id. at 388 .

66. Id. at 388-89.

67. Id. at 389 .

68. Id.

69. Id. at 390.

70. Commonwealth v. Claycomb, 566 S.W.3d 202, 204 (Ky. 2018).

71. Id.

72. See id. at 217 ; compare Ky. CONST. $§ 14$ (“All courts shall be open, and every person for an injury done him in his lands, goods, person or reputation, shall have remedy by due course of law, and right and justice administered without sale, denial or delay."), with IND. CONST. art. $1 \S$ 12 ("All courts shall be open; and every person, for injury done to him in his person, property, or reputation, shall have remedy by due course of law. Justice shall be administered freely, and without purchase; completely, and without denial; speedily, and without delay."). 
courts provision applies to both the legislature and the judiciary, ${ }^{73}$ while Indiana had applied their open courts provision only to the judiciary. ${ }^{74}$ Although delays are inherent in court proceedings, the court held the delay caused by medical review panels was unconstitutional because it "usurp[ed]" a plaintiff's "freedom to access the adjudicatory method of his or her choosing at the time of his or her choosing." 75 The mandatory delay caused by the Kentucky statute was troublesome to the court because it was "as though no 'course of law' [was] taking place whatsoever" during the delay, resulting in no "due course of law" in the proceedings. ${ }^{76}$

\section{ARe the Goals of Medical ReVIEW Panels Being Met?}

With states such as Kentucky ruling medical review panels unconstitutional and frustrations from both sides about the delays caused by them, there may be areas in the Indiana Act that could be modified to reduce the amount of time the panel process takes. Indiana's panel process was held constitutional in 1980, but the increasing delays are more unreasonable than they were forty years ago. ${ }^{77}$

When medical review panels were initially implemented across the country, legislators had many goals they hoped to achieve. The New Hampshire medical review panel statute includes a list of goals that are typical of many other states that have enacted this type of tort reform. These goals include: (1) making medical liability insurance available and affordable; (2) protecting patients and providing access to medical care for consumers; (3) keeping down the costs of resolving medical negligence disputes; (4) resolving claims speedily and inexpensively, preferably without resorting to the court system; and (5) identifying early in the process which claims have merit. ${ }^{78}$

Over the years, studies have been conducted to examine these goals to see if the panels are achieving what they were implemented to do. ${ }^{79}$ While the results of these studies have varied, many have shown that the panels may not be as effective as they were originally thought to be. ${ }^{80}$ In 1985 , a study concluded that medical review panels did not have an effect on reducing the total number of medical malpractice claims filed ${ }^{81}$ On the contrary, the study found that these

73. Claycomb, 566 S.W.3d at 217.

74. Smith v. Ind. Dep't of Corr., 883 N.E.2d 802, 808 (Ind. 2008) (“[T]he Open Courts Clause does not prohibit all conditions on access to the courts, but it does prevent the legislature from arbitrarily or unreasonably denying access to the courts to assert a statutory or common law cause of action that is in itself unmodified and unrestricted.").

75. Claycomb, 566 S.W.3d at 213 (emphasis omitted).

76. Id.

77. See Johnson v. St. Vincent Hosp., 273 Ind. 374 (1980).

78. N.H. Rev. Stat. ANN. § 519-B:1(I) (2020).

79. Eggen, supra note 1, at 24.

80. Id.; see also Nussbaum, supra note 11, at 271.

81. Eggen, supra note 1, at 24; Patricia Munch Danzon, New Evidence on the Frequency and Severity of Medical Malpractice Claims 21 (1986); see Nussbaum, supra 
statutes may even encourage individuals to file claims because they could "reduc[e] the cost to the plaintiff of obtaining expert testimony." medical review panels may not reduce the time or cost of litigating medical malpractice claims. ${ }^{83}$ In most cases, in order to provide all the requisite evidence to the panel members, both parties will have to conduct discovery at an earlier stage of the case, which will delay the panel and add costs to litigation. ${ }^{84}$ A 1992 study found that states with medical review panels had a higher rate of malpractice litigation. ${ }^{85}$ On one hand, this finding could indicate that states with higher litigation are more likely to implement screening panels. ${ }^{86}$ On the other hand, this could also indicate that the panels are not reducing the litigation as they were thought to do. ${ }^{87}$

While these studies show that the panel process can be ineffective, others have taken an opposing view and found that any downfalls involved with the statutes are outweighed by the benefits gained ${ }^{88}$ In 2008, Pinnacle Actuarial Resources, Inc. concluded that states with "screening panels" had malpractice insurance rates about $20 \%$ below the national average. ${ }^{89}$ These states also had lower claim costs and a higher rate of cases closed without payment. ${ }^{90}$ The study also found panels typically heard claims within six months of the filing, which would make them very effective. ${ }^{91}$ While this study vindicates supporters of medical review panels, it should be noted that this study was done at the request of the American Medical Association..$^{92}$ As with many health care providers and their organizations, the American Medical Association is an organization that favors medical review panels. ${ }^{93}$

While delays in any panel process are inevitable, the statutory language can be a factor in the actual length of the delay. ${ }^{94}$ State statutory language varies in how long the process should last. ${ }^{95}$ Some states, such as Indiana, provide a

note 11 , at 271 .

82. DANZON, supra note 81 (footnote omitted).

83. Nussbaum, supra note 11, at 271.

84. Id

85. Eggen, supra note 1, at 25; CATHerine T. Struve, ExPertise in Medical MalPractice Litigation: Special Courts, Screening Panels, And Other Options 56 (2003).

86. Eggen, supra note 1, at 25; STRUVE, supra note 85, at 60.

87. See Eggen, supra note 1, at 25; see also STRUVE, supra note 85, at 64-65.

88. Eggen, supra note 1, at 25.

89. Id.; Litigation Screening Panels on Trial: Are They Working?, Am. Med. News (Aug. 3, 2009), https://amednews.com/article/20090803/profession/308039980/4/ [https://perma.cc/ DWC3-G83H].

90. Eggen, supra note 1, at 25.

91. Litigation Screening Panels on Trial: Are They Working?, supra note 89.

92. Id.

93. Id

94. See Eggen, supra note 1.

95. See id. 
deadline based upon the date the final panel member is selected. ${ }^{96}$ These deadlines vary from thirty to 180 days. ${ }^{97}$ Some states give limitations within which the panel hearing must be held, and still, others do not specify a time period in their statutes at all. ${ }^{98}$ As seen in the Kentucky decision in Claycomb, even with statutory deadlines, courts have struck down these statutes due to their delays. ${ }^{99}$ And, as many of these states have shown, the deadlines do little to prevent panels from lasting months or even years past the deadline. ${ }^{100}$

While Kentucky may be the most recent to rule their statute unconstitutional, it is not alone in viewing these panels as problematic. In 1983, the Rhode Island Supreme Court found that its medical review panel statute unconstitutional. ${ }^{101}$ The court held the statute violated the Equal Protection Clause of the United States Constitution because the insurance crisis that existed when the statute was enacted was no longer a crisis that needed a statutory remedy. ${ }^{102}$ The Supreme Court of Missouri also held its statute unconstitutional in 1979. ${ }^{103}$ This court found that the statute violated the plaintiff's right of access to the courts by imposing what was described as an "arbitrary delay." ${ }^{04}$ In 1980, the Pennsylvania medical review statute was held unconstitutional "because the delays involved in processing the[] claims under the prescribed procedures set up under the [statute] result[ed] in an oppressive delay and impermissibly infringe[d] upon the constitutional right to a jury." 105 The New Hampshire state bar has been critical of its State's screening panel statute. Although there is a statutory time limit of eleven months, a Superior Court report in 2008 found that the average time between the start of the screening panel process and the start of the panel hearing was much longer, at 560 days. ${ }^{106}$ This average time of 560 days is even longer than the average time to trial in New Hampshire. ${ }^{107}$

\section{WHAT'S CAUSING THE DELAY?}

While a quick process may have been envisioned when medical review

96. See id.

97. See id.

98. See id.

99. See id.; Commonwealth v. Claycomb, 566 S.W.3d 202, 205 (Ky. 2018) ("Any action involving a dependent claim accruing after June 29, 2017, shall be immediately and automatically stayed until . . . (b) Nine (9) months after the filing of the proposed complaint if the panel has not given its opinion.").

100. See Eggen, supra note 1.

101. Boucher v. Sayeed, 459 A.2d 87, 93 (R.I. 1983).

102. Id.

103. State ex rel. Cardinal Glennon Mem'l Hosp. for Children v. Gaertner, 583 S.W.2d 107, 110 (Mo. 1979).

104. Id.

105. Mattos v. Thompson, 421 A.2d 190, 196 (Pa. 1980).

106. Eggen, supra note 1, at 27.

107. Id. 
panels were first created, the delays in the system now can be extreme. A backlog of cases is one cause of the delay. ${ }^{108}$ An example of the backlog is the Commonwealth of Pennsylvania, in which a panel process was created with a panel of seven but the program was later terminated, with officials concluding that the process was "an ambitious state program" that fell "woefully short of [its] promise." ${ }^{109}$ While the process was in place, there were 2,466 claims filed and a mere nine cases reached the hearing stage. ${ }^{110}$ Further, less than $10 \%$ of the claims had been settled or discontinued. ${ }^{11}$ One can only imagine the backlog now, around forty years later. The backlog of cases in other states is undoubtedly causing similar issues.

In 2015, Indiana lawmakers received varying opinions about the medical review panel process. ${ }^{112}$ Testimony from an attorney on behalf of the Indiana Trial Lawyers Association, an organization of plaintiff's attorneys, revealed that, in the attorney's experience, the average time for a panel decision to be rendered after the panel is formed is over two years when it should ideally be completed in a year or less. ${ }^{113}$ While there are deadlines throughout the panel process, including the panel formation and selection, an attorney who defends health care providers testified that nobody wants the deadlines enforced $95 \%$ of the time. ${ }^{114}$ One reason for this may be that the panel process is seen as "informal," so the need to meet deadlines is not great. ${ }^{115}$ There are remedies for intentional delays in the process, but it is rare for attorneys to enforce the deadlines through the courts. ${ }^{116}$

Delays can originate at the very beginning of the panel process when the parties choose an attorney to be the panel chair. ${ }^{117}$ If the parties agree on who should serve as the panel chair, this stage of the process is completed. ${ }^{118}$ However, agreement amongst the parties is rare. ${ }^{119}$ Without a consensus, the clerk of the Indiana Supreme Court provides a random list of five attorneys to the

108. Nussbaum, supra note 11, at 271; Nicole L. Kaufman, The Demise of Medical Malpractice Screening Panels and Alternative Solutions Based on Trust and Honesty, 28 J. LEGAL MED. 247, 256 (2007).

109. Edelson v. Soricelli, 610 F.2d 131, 136 (3d Cir. 1979); Kaufman, supra note 108.

110. Edelson, 610 F.2d at 136; Kaufman, supra note 108.

111. Edelson, 610 F.2d at 136; Kaufman, supra note 108.

112. Dave Stafford, The Waiting Game Delays Medical Malpractice Claims Going to Court, IND. LAw. (Oct. 6, 2015), https://www.theindianalawyer.com/articles/38382-the-waiting-gamedelays-medical-malpractice-claims-going-to-court [https://perma.cc/NA2X-YFEZ].

113. Id.

114. Id.

115. Id.

116. Id.

117. Id.

118. Id.

119. Id. 
parties and the parties take turns striking the names until one is left. ${ }^{120} \mathrm{~A}$ similar process is implemented when choosing the members of the panel. ${ }^{121}$ If the parties agree to a panelist nominated by the other side, the process would be much quicker, but again, agreement of the parties is rare and either side can challenge nominations made by the opposing party. ${ }^{122}$ After the panel is formed, the statute provides that an opinion should be rendered within 180 days. ${ }^{123}$ However, this deadline is often extended by requests of the parties, due to disputes relating to discovery, or other issues. ${ }^{124}$

The number of panel members can also have an effect on the length of time the panel process takes. ${ }^{125}$ States vary between three, as in Indiana, to seven members. ${ }^{126}$ Fewer panelists make it easier to coordinate a date and time for the panel to convene, and it takes less time to form the panel. ${ }^{127}$ However, when there are multiple defendants, which is very common in malpractice cases, delays are likely to be caused by the parties having to decide which three specialties will be chosen for the panel and which ones will be left out. ${ }^{128}$ Additionally, the level of cooperation between physicians and attorneys can be very low. ${ }^{129}$ Asking a group of busy doctors to take time away from work to study and examine what could be hundreds of pages of submissions and medical records does not always result in a quick convening of the panel. Not only do the doctors need to find the time to convene the panel and review the materials but they also need to find a time that works for all of the panelists which can contribute to the already belated panel process.

\section{IS THERE STILL A MEDICAL MALPRACTICE CRISIS?}

By 2009 , there were approximately $29.5 \%$ fewer medical malpractice claims in the United States than in 2003. ${ }^{130}$ While some believe there is still a health care insurance crisis in the United States, others disagree. ${ }^{131}$ This debate is very

120. Id.

121. Id.

122. Id.

123. IND. CODE $\S 34-18-10-13$ (2020).

124. Stafford, supra note 112 (discussing how the Indiana Court of Appeals reinstated a medical malpractice claim from 2007 that was prolonged due to delays and discovery disputes and how the panel chair informed the case's parties that deadlines would not be strictly enforced).

125. See Eggen, supra note 1.

126. Id. at 8 .

127. William A. Ramsey, DTCI: The Right to a Meaningful Medical Review Panel, InD. LAw. (Sept. 18, 2019), https://www.theindianalawyer.com/articles/dtci-the-right-to-a-meaningfulmedical-review-panel [https://perma.cc/Q3U4-A8AB].

128. Id.

129. Allen K. Hutkin, Resolving the Medical Malpractice Crisis: Alternatives to Litigation, 4 J.L. \& HeALTH 21, 38 (1989).

130. Eggen, supra note 1, at 22.

131. Id.; but see Chad Terhune, Top Republicans Say There's a Medical Malpractice Crisis. 
politically divided, with Republicans more likely than Democrats to believe there is a crisis. ${ }^{132}$ For this reason, Republicans tend to be more in favor of medical review panel statutes. ${ }^{133}$ Many believe that there are too many frivolous lawsuits that increase insurance premiums and are harming the businesses of doctors and other health care professionals. ${ }^{134}$ Some have argued if doctors are afraid of too much litigation, they may order "excessive tests and treatments" which would increase the price of health care costs. ${ }^{135}$ High rates of litigation can also deter higher-risk specialists from practicing in certain states due to the increased probability they will be sued. ${ }^{136}$ Additionally, even though there may be less of a malpractice crisis than years ago, that does not mean that one will arise again. ${ }^{137}$

However, researchers and experts on the other side of this debate, including many Democrats, believe there is not a malpractice crisis in the country right now. ${ }^{138}$ They say this country has been free from this crisis for more than ten years. ${ }^{139}$ Some on this side of the argument believe that reform measures, such as medical review panels, do not address the root of the problem: medical errors. ${ }^{140}$ In the last few years, studies have found that medical errors are the third leading cause of death in the United States. ${ }^{141}$ Many on this side of the debate therefore argue that the best way to reduce litigation would be to address that problem first. ${ }^{142}$

As recent as 2017, a majority of Republicans believed our country was still in the midst of a medical malpractice crisis. ${ }^{143}$ Tort reform was vowed to be a large part of the replacement to the Affordable Care Act. ${ }^{144}$ However, there are still groups that disagree. ${ }^{145}$ Experts in the industry and researchers believe that the medical malpractice insurance industry in the United States is "running smoothly" and the country has not been in the middle of a malpractice crisis for

Experts Say There Isn't, WASH. Post (Dec. 30, 2016), https://www.washingtonpost.com/news/toyour-health/wp/2016/12/30/top-republicans-say-theres-a-medical-malpractice-crisis-experts-saythere-isnt [https://perma.cc/NF8C-PZBC].

132. Terhune, supra note 131 .

133. Id.

134. Id.

135. Id.

136. Id.

137. See id.

138. Id.

139. Id.

140. $I d$.

141. $I d$.

142. Id.

143. Chad Terhune, Leading Republicans See a Costly Malpractice Crisis - Experts Don't, Kaiser Health News (Jan. 4, 2017), https://khn.org/news/leading-republicans-see-a-costlymalpractice-crisis-experts-don't/ [https://perma.cc/VW7E-TNTY].

144. Id.

145. Id. 
over a decade. ${ }^{146}$ According to one of the nation's largest malpractice insurers, Doctors Company, physicians were paying less for malpractice insurance in 2017 than they were in 2001 and the number of claims has "dropped by half since 2003." 147

In backing tort reforms, such as medical review panels, Republicans argue that they are implemented with the goal of making it easier to defend against malpractice suits and raise the burden of proof for plaintiffs. ${ }^{148}$ In addition, Republicans have been backing caps on damages, something that Indiana implemented in the Act. ${ }^{149}$ The Republican plan to replace the Affordable Care Act in 2017 looked to California and other states as examples to show that states that have tort reforms in this area experience an increase of doctors, an increase in access to specialists, and a reduction in medical liability insurance premiums. ${ }^{150}$ Researchers that agree with the Democratic side of this debate argue that damage caps are not the only factor that keeps insurance costs down; "economic cycles and insurers' investment returns" are also factors that affect insurance costs. ${ }^{151}$

Additionally, advocates for the Democratic side of this argument state that Republicans may be going too far and are reducing access to the justice system and preventing plaintiffs to recover fair compensation for actual medical mistakes. ${ }^{152}$ It is argued that the country should be focused on the bigger problem: reducing overall patient harm. ${ }^{153}$

The politics of tort reform could explain why some states are more likely to rule medical malpractice panels unconstitutional while others are upholding a very similar statute. In 1980 when it decided Johnson, the majority of the Indiana Supreme Court was appointed by a Republican governor and remains that way today. ${ }^{154}$ Conversely, a study done in 2016 found that the Supreme Court in Kentucky tends to be much more liberal. ${ }^{155}$ Kentucky has traditionally been a more Democratic state, but in 2016, Republicans gained control of the Senate, the House of Representatives, and the State had a Republican governor. ${ }^{156}$ This political changeup occurred immediately before the medical review panel statute

146. Id.

147. Id.

148. Id.

149. Id.; see IND. CODE $§ 34-18-14-3$ (2020).

150. Terhune, supra note 143.

151. Id.

152. Id.

153. Id.

154. See Indiana Supreme Court, BALlotPEDIA, https://ballotpedia.org/Indiana_Supreme_ Court [https://perma.cc/DHR6-R7KY] (last visited Oct. 30, 2019).

155. Brian T. Fitzpatrick, The Ideological Consequences of Selection: A Nationwide Study of the Methods of Selecting Judges, 70 VAND. L. REV. 1729, 1742 (2017).

156. Jack Brammer \& Linda Blackford, Republicans Take the Kentucky House After 90 Years of Democratic Control, LeXington Herald Leader (Nov. 8, 2016), https://www.kentucky. com/news/politics-government/article1 13464563.html [https://perma.cc/69PG-C9CN]. 
was introduced and passed. ${ }^{157}$ The vote in the Kentucky Senate to pass the medical review panel statute was very partisan. ${ }^{158}$ Of the Republicans that voted, all twenty-one of them voted yes to the passing of the bill. ${ }^{159}$ One Democratic senator voted to pass the bill, while the other thirteen Democrats voted no. ${ }^{160}$ Kentucky is just one example of how important the members of a Supreme Court can be in implementing medical review panels. Even though the bill passed the Senate, it did not get past the Kentucky Supreme Court. Although Indiana and Kentucky have similar party control in the Governor's office and Legislature at this time, the members of the Supreme Court are an important distinction that helps explain the difference in opinions of strikingly similar statutes.

\section{ALtERNATIVES TO MEDICAL REVIEW PANELS}

With statutes similar to Indiana's Medical Malpractice Act being struck down by courts and causing large delays, one can imagine that a challenge will be brought to the statute in the future. While the statute was ruled constitutional in $1980,{ }^{161}$ the effects of the statute are very different today. When the Act was enacted in 1975, only one complaint was filed. ${ }^{162}$ Ten years later, a total of 4,225 complaints had been filed with only 1,171 resolved. ${ }^{163}$ As of 1983 , complaints took 23.4 months to go through the panel process. ${ }^{164}$ In 2015 alone, the State saw one of the highest numbers of complaints filed with a total of $1,205 .{ }^{165}$ The number of complaints has lowered since 2015, with 987 in 2016 and 863 in 2017. ${ }^{166}$ However, with complaint numbers still high and a backlog in the courts, there are ways to improve the statute to ensure it is constitutionally strong in the face of a challenge.

\section{A. Affidavit of Merit}

Approximately twenty-nine states use affidavits of merit in medical

157. See Bruce Schreiner, Kentucky Set to Create Medical Malpractice Claim Review Panels, INSURANCE J. (Mar. 20, 2017), https://www.insurancejournal.com/magazines/mag-features/2017/ 03/20/444684.htm [https://perma.cc/GP6T-PA2Q].

158. SB 119 - Establishes Medical Malpractice Claims Review Panel - Voting Record, Vote SMART, https://votesmart.org/bill/votes/46819\#.Xm_XSC3Mwcg [https://perma.cc/U2W9-HSB9] (last visited Mar. 16, 2020).

159. Id.

160. Id.

161. See Johnson v. St. Vincent Hosp., 273 Ind. 374 (1980).

162. Kemper et al., supra note 9, at 1133.

163. Id.

164. Id.

165. Ind. DeP'T OF Ins., IndiAnA PATIENT's COMPENSATION Fund 2018 ANNUAL REPORT 27 (2019), https://www.in.gov/idoi/files/2018\%20Combined\%20Annual\%20Report\%20FINAL.pdf [https://perma.cc/QKV9-ACV5].

166. Id. 
malpractice claims. ${ }^{167}$ These affidavits are signed by a health care provider who attests to the merits of the malpractice claim. ${ }^{168}$ This product of tort reform is used to accomplish similar goals to that of medical review panels, including: (1) decreasing the number of suits filed; (2) decreasing the sum of money put aside for settling claims of uncertain value; (3) restricting the kinds and sums of liability insurance professionals must have; and (4) restricting the number and kinds of decisions made out of fear of a possible lawsuit. ${ }^{169}$

The hope is that the health care professional's opinion, having signed the affidavit under oath, will reduce the number of frivolous medical malpractice claims filed. ${ }^{170}$ While many states require these affidavits with a claim of malpractice, the states differ as to the content of the affidavit and who can execute the same. ${ }^{171}$ Generally, the attestations require the health care provider to state that he or she is "substantially familiar" with the applicable standard of care. ${ }^{172}$ States may require that the health care provider have experience in the field within a certain timeframe, such as within a certain number of years before the case, and some states allow professors of professional schools to qualify as well. ${ }^{173}$ The content of affidavits of merit varies from a simple statement after the relevant facts, such as "there is a "reasonable and meritorious cause" for filing the claim, to the health care provider having to specifically "identify[] the departure from the relevant standard of care." ${ }^{174}$ Some states require the affidavit to state that the failure to meet the standard of care was the "proximate cause" of the injury. ${ }^{175}$ There are also states that require an attorney to sign the affidavit along with the health care provider. ${ }^{176}$ The attorney may need to "identify who they plan to call as expert witnesses should the matter go to trial, detail the facts and opinions the expert will testify to, and summarize the grounds for each opinion." 177 Similar to an affidavit of merit, a "certificate of consultation" is used

167. Christine Funk, Affidavits of Merit in Medical Malpractice Cases, EXPERT InST. (Jan. 25, 2018), https://www.theexpertinstitute.com/affidavits-merit-medical-malpractice-cases/ [https://perma.cc/35AY-C2X4]; see Goldberg Segalla LLP, 50-State Survey of Affidavit of Merit Statutes, Prof. LiABILITY MATTERS, https://professionalliabilitymatters.com/wp-content/uploads/ 2015/02/GS-3471935-v3-PL_Matters_AOM_Chart_REVISED.pdf[https://perma.cc/8A6J-GEVU] (last updated Feb. 2015).

168. See Funk, supra note 167.

169. Id.

170. Id.

171. Id.

172. Id.

173. Id.

174. Id.

175. Id.

176. Id.; see, e.g., N.Y. C.P.L.R. § 3012-a (McKinney 2020) ("In any action for medical . . malpractice, the complaint shall be accompanied by a certificate, executed by the attorney for the plaintiff ....").

177. Funk, supra note 167. 
in some states. ${ }^{178}$ This certificate is filed by the plaintiff and provides the facts and the attorney's consultation with at least one qualified health care provider. ${ }^{179}$ The purpose is to show that the attorney believes that there is a "valid basis" for filing the malpractice claim. ${ }^{180}$

While affidavits of merit are also an extra hurdle for plaintiffs to overcome before filing a lawsuit with the courts, they are a low-cost way to prevent frivolous claims. ${ }^{181}$ The cost of an affidavit of merit can be as low as $\$ 500$ whereas the average cost of a medical review panel in Indiana is approximately $\$ 3,000 .{ }^{182}$ In states where affidavits of merit are required for medical malpractice cases, the constitutionality of the statutes can be challenged similar to the challenges of medical review panels. ${ }^{183}$ Arizona passed statutes requiring affidavits of merit in 2004 and has had multiple challenges to the statutes since their passing. ${ }^{184}$ The Arizona courts have ultimately upheld the constitutionality of the statutes after access to the courts arguments, equal protection challenges, and separation of powers challenges. ${ }^{185}$

Along with the low-cost of affidavits of merit, the shorter delay to court access is an advantage of this product of tort reform. Referring to the length of medical review panels, the Indiana Trial Lawyers Association takes the view that the panels should not be mandatory if the plaintiff produces an affidavit of merit. ${ }^{186}$ This proposition could be beneficial in that it would allow plaintiffs to choose how to proceed. If they preferred to bring their claim to a medical review panel and try to obtain a favorable panel opinion, they would be allowed to do so. However, if they believe their best route is obtaining an affidavit of merit, they could choose that.

Obtaining an affidavit of merit requires some time, but it does not entail the same delays as medical review panels caused by selecting the panel chair, forming the panel, and extensions of deadlines by attorneys. Additionally, the statutory deadlines for affidavits of merits are significantly shorter than those relating to medical review panels. For example, in Indiana, the medical review panel should ideally render its opinion 180 days after the panel has been

178. Id.

179. Id.

180. Id.

181. Meryl J. Thomas, The Merits of Procedure vs. Substance: Erie, Iqbal, and Affidavits of Merit as MedMal Reform, 52 ARIZ. L. REV. 1135, 1140 (2010).

182. Mary Markle, How Affidavit of Merit Requirements Are Ruining Arizona's Medical Liability System, 46 ARIz. ST. L.J. 407, 411 (2014); Medical Review Panel, Ind. DeP'T InS., https://www.in.gov/idoi/2985.htm [https://perma.cc/5VZL-WSRB] (last visited Feb. 1, 2020).

183. See Markle, supra note 182.

184. Id. at 409,410 .

185. Id. at 410; see Governale v. Lieberman, 250 P.3d 220 (Ariz. Ct. App. 2011); see Baker v. Univ. Physicians Healthcare, 269 P.3d 1211 (Ariz. Ct. App. 2012); see Seisinger v. Siebel, 203 P.3d 483 (Ariz. 2009); see Jilly v. Rayes, 209 P.3d 176 (Ariz. Ct. App. 2009).

186. Stafford, supra note 112. 
formed. ${ }^{187}$ This does not take into account how long the panel formation process can take, and the average time of medical review panels shows that they often do not meet the 180-day deadline. ${ }^{188}$ In states that require affidavits of merit, the deadline is much shorter than 180 days. ${ }^{189}$ While the deadlines to file an affidavit of merit can range from the day the complaint is filed ${ }^{190}$ up to 180 days after the complaint has been filed, ${ }^{191}$ many states require the affidavit to be filed sixty or ninety days after the complaint has been filed. ${ }^{192}$

Kentucky is an example of a state that has recently adopted affidavits of merit. After the Kentucky Supreme Court ruled their medical malpractice statute unconstitutional in 2018, the State enacted new legislation that requires medical malpractice lawsuits be accompanied by a "certificate of merit." 193 The legislation requires a plaintiff to consult with at least one qualified expert who concludes that "there is a reasonable basis to commence the action." 194 The bill also contains some exceptions to the requirement. ${ }^{195}$ If a plaintiff does not have time to obtain a certificate and have an expert review the case before the statute of limitations runs, they may not need to obtain the certificate. ${ }^{196}$ Additionally, if a plaintiff has "made at least three ... separate good-faith attempts" with different experts who do not agree to consult on the case, the requirement may be waived if none of the experts contacted "gave an opinion that there was no reasonable basis to commence the action." 197 Lastly, the certificate is not required if the plaintiff is relying "solely on one ... or more causes of action for which expert testimony is not required." 198

187. IND. CODE $§ 34-18-10-13$ (2020).

188. See Eggen, supra note 1, at 27.

189. State Laws Chart II: Liability Reform, AMA, https://www.ama-assn.org/sites/amaassn.org/files/corp/media-browser/premium/arc/state-laws-chart-2_0.pdf [https://perma.cc/R7RVUUT4] (last updated Sept. 2017).

190. See Ariz. Rev. Stat. Ann. § 12-2603 (2020); see Conn. Gen. Stat. § 52-190a (2020); see Del. Code AnN. tit. 18, § 6853 (2020); see Fla. Stat. § 766.104 (2020); see Ga. Code AnN. $\S 9-11-9.1$ (2020).

191. See Minn. Stat. $§ 145.682$ (2020).

192. See Goldberg Segalla LLP, supra note 167; see Colo. Rev. StAT. § 13-20-602 (2020); see Md. Code AnN., Health-Gen. § 3-2A-04 (West 2020); see N.J. Stat. AnN. § 2A:53A-27 (West 2020); see N.Y. C.P.L.R. § 3012-a (McKinney 2020); see TENN. CodE ANN. § 29-26-122 (West 2020).

193. Ky. Rev. Stat. AnN. § 411.167 (West 2020); Al Cross, Bill on Bevin's Desk Would Require a Malpractice Lawsuit to Certify That an Expert Has Said It Has a Reasonable Basis to Be Filed, Ky. Health News (Mar. 22, 2019), http://ci.uky.edu/kentuckyhealthnews/2019/03/ 22/bill-on-bevins-desk-would-require-a-malpractice-lawsuit-to-certify-that-an-expert-has-said-ithas-a-reasonable-basis-to-be-filed/ [https://perma.cc/MMQ7-QVJ4].

194. § 411.167.

195. See id.; see also Cross, supra note 193.

196. § 411.167; Cross, supra note 193.

197. $\S 411.167$.

198. Id. 


\section{B. Arbitration and Mediation}

Other alternatives to medical review panels are binding arbitration and mediation. Binding arbitration differs from medical review panels in that there are currently no states that require binding arbitration in medical malpractice cases. ${ }^{199}$ Arbitration can be chosen by the parties through private contracts and some states have legislation that authorizes this kind of agreement. ${ }^{200}$ The agreements are usually presented to the patient either when they are being admitted to receive treatment, or before they are able to receive treatment. ${ }^{201}$ Arbitration is similar to medical review panels in that one of the goals is to reduce the cost of medical malpractice litigation. ${ }^{202}$ However, also similar to medical review panels, the goal of reducing costs may not be working the way it was hoped. ${ }^{203}$ Arbitration, unlike other tort reform alternatives, does not attempt to encourage the early settlement of cases. ${ }^{204}$ This process gives the power to the arbitrator to determine whether or not "a standard of care was met.". ${ }^{05}$ The arbitrator can then "assign[] fault, and award damages in compensation." 206

The goals for binding arbitration in medical malpractice cases are greater efficiency and "reduced medical liability system costs," but it is possible that these goals are not being met. ${ }^{207}$ One study has found that insurance premiums actually went up in states that permitted binding arbitration, while another study found that areas with arbitration correlated with an increased frequency of claims being filed and paid. ${ }^{208}$ Included in these are small claims that are unlikely to proceed to court due to the costs. ${ }^{209}$ While some support arbitration, it seems there is a good reason that this form of tort reform is not very common. ${ }^{210}$

There may not be an incentive for states to use binding arbitration because it is likely not going to be the most favorable tort reform option for either party. ${ }^{211}$

199. Nussbaum, supra note 11, at 272 .

200. Id. at 274 .

201. Alba Reyes Santos, Medical Malpractice Arbitration Agreements: Is Uniformity the Solution?, Hous. J. HeAlth L. \& POL'Y 1, http://www.law.uh.edu/Healthlaw/perspectives/2012/ Alba\%20Reyes\%20Santos--med\%20mal\%20arbitration.pdf [https://perma.cc/8P6U-VRFW] (last visited Mar. 24, 2020).

202. Nussbaum, supra note 11 , at 276.

203. Id.

204. Id. at 273.

205. Id.

206. Id.

207. $I d$. at 276 .

208. Id.

209. Id.

210. Id.

211. Alex Stein, The Incentives to Arbitrate Medical Malpractice Disputes, Bill Health (Aug. 29, 2013), https://blog.petrieflom.law.harvard.edu/2013/08/29/the-incentives-to-arbitrate- 
Whether or not arbitration is used usually depends on whether or not the health care provider chooses to include an arbitration clause in the contract that is signed by the patient. ${ }^{212}$ Arbitration agreements need to be knowingly and voluntarily signed by the patient, which means that their attention should be drawn to the arbitration agreement before they sign. ${ }^{213}$ For patients, this could create some uncertainty. ${ }^{214}$ If patients believe that their doctor is trying to ensure they do not take the normal litigation route, patients could become suspicious and wonder whether the normal litigation route would be more beneficial to them. ${ }^{215}$ Doctorpatient relationships are important and doctors may not want to hurt this relationship by fostering suspicion in their patients before they are even treated. ${ }^{216}$ There are also many cases in which patients "argue that they did not knowingly waive their right to trial by jury and that they did not understand or know what they were signing." ${ }^{217}$ If this is true, a patient will not be bound by the arbitration clause. ${ }^{218}$ Patients may also believe that they would receive a larger award if they went before a jury. ${ }^{219}$ Medical malpractice claims can be emotional, which could lead patients to want to litigate before a jury and provide them with the emotional, compelling arguments for their case. ${ }^{220}$

Although arbitration may not be ideal for patients or doctors, there have been federal and state attempts to promote arbitration agreements. In 1925, the Federal Arbitration Act ("FAA") was enacted with two purposes: (1) "to end the feeling of animosity towards arbitration," and (2) "to make courts enforce arbitration agreements involving interstate commerce and maritime transactions." 221 When the FAA applies, state laws regarding arbitration are preempted by the federal statute. ${ }^{222}$ Thirty years after the FAA was passed, the National Conference of Commissioners on Uniform State Laws published the Uniform Arbitration Act ("UAA") that was created to "offer[] the states arbitration mechanisms that are more versatile than the FAA." 223 Even with these attempts to regulate arbitration among the states, many states have adopted their own tort reforms, creating different standards and requirements for claims. ${ }^{224}$ With so many different standards for arbitration across the United States, there can be questions about whether or not arbitration will be enforced by the courts in differing states, and

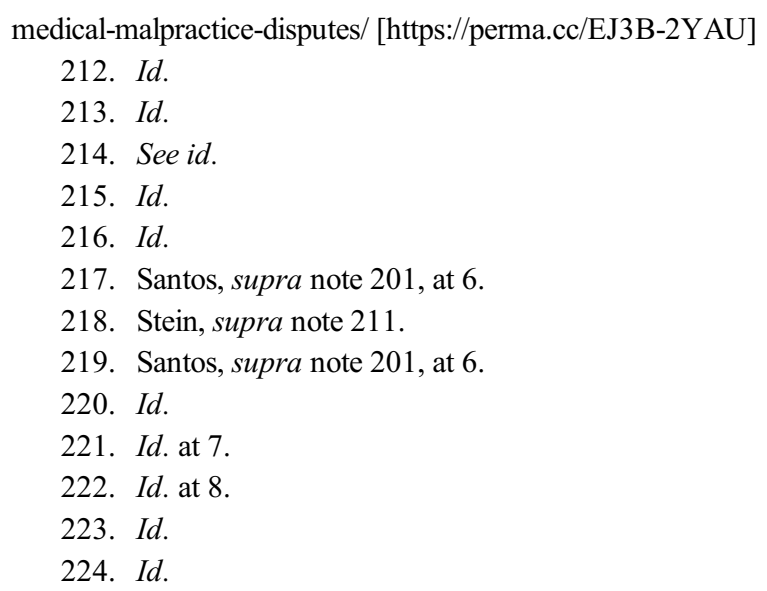


whether or not patients will feel comfortable entering these agreements. ${ }^{225}$ These questions could be factors that are deterring the use of arbitration in these cases. ${ }^{226}$

Mediation can also serve as an alternative tort reform process that could reduce the timing and costs of other alternatives such as medical review panels. ${ }^{227}$ Different from both medical review panels and binding arbitration, mediation serves to be a voluntary, informal negotiation that can also attempt to address communication between health care providers and patients. ${ }^{228}$ In a mediation, "a neutral third person ... helps the parties" in a dispute negotiate an acceptable resolution. ${ }^{22}$ The confidentiality of discussions in mediations can encourage parties to explain to each other what went wrong and defendants can make "benevolent gestures without fear these actions will later be used in court."230 Mediation is less expensive for courts and uses fewer court resources than medical review panels. ${ }^{231}$

As with all tort reforms, there are benefits and disadvantages to mediation. Some benefits of mediation include the ability to have more control over the resolution of the case, the ability to schedule a mediation as soon as the parties agree to mediation, and voluntary settlement of the case. ${ }^{232}$ Additionally, mediation can "promote better relationships through cooperation, creative problem-solving, and improved communications." ${ }^{233}$ Mediation can also be beneficial because the parties are creating a settlement agreement themselves so they are more like to abide by the agreement. ${ }^{234}$ Some may view mediation as unfavorable for their case because they would rather have their case decided by a judge or jury. ${ }^{235}$ Mediation might not always be the most effective way of settling a case if it is early on and the parties do not have sufficient information about each other's competing arguments. ${ }^{236}$ Further, if there is no settlement reached at the mediation, then time and money have been spent on alternate dispute resolution and the case will have to continue to trial anyway. ${ }^{237}$

225. See id.

226. See id. at 8-9.

227. See Nussbaum, supra note 11 , at 277.

228. Mediation, A.B.A., https://www.americanbar.org/groups/dispute_resolution/resources/ DisputeResolutionProcesses/mediation/ [https://perma.cc/6E3G-2BCZ] (last visited Nov. 29, 2020).

229. Steven Gosset, Mediation Can Help Resolve Malpractice Lawsuits, Study Finds, but Doctors, Lawyers Remain Wary, PR WEB (Dec. 13, 2010), https://www.prweb.com/releases/2010/ 12/prweb4892554.htm [https://perma.cc/797Z-JPTU].

230. Nussbaum, supra note 11 , at 279 (footnote omitted).

231. Id.

232. Mediation/Alternative Dispute Resolution, IND. Jud. BRANCH, https://www.in.gov/ judiciary/selfservice/2360.htm [https://perma.cc/UV2X-7Q7M] (last visited Mar. 24, 2020).

233. Id.

234. Id.

235. Id.

236. $I d$.

237. $I d$. 
Even though mediation has some benefits, the disadvantages seen by doctors, hospitals, and lawyers may prevent mediation from becoming widely used in medical malpractice cases. ${ }^{238}$ A study found that when mediation was used, benefits of the practice included reduced costs of litigation and "the potential to offer closure to plaintiffs and ensure that procedures are changed in hospitals to prevent recurrences of the error that sparked the lawsuit." ${ }^{239}$ The study looked at "[thirty-one] cases from [eleven] nonprofit hospitals in New York City in 2006 and 2007 that went to mediation." ${ }^{240}$ Around $70 \$$ of the cases studied settled during or after mediation. ${ }^{241}$ The settlement amounts ranged from " $\$ 35,000$ to $\$ 1.7$ million." ${ }^{242}$ Even with the benefits of mediation, the study recognized challenges that may not lead many cases to take advantage of mediation. ${ }^{243}$ The study found that a major challenge of mediating medical malpractice cases is the absence of doctors at the mediations. ${ }^{244}$ The authors of the study viewed this as an issue because "it is possible that plaintiffs would have been even more satisfied with the process had their physicians demonstrated respect and caring" by taking the time to attend and participate in the process. ${ }^{245}$ Attorneys for the defendants and physicians provided some reasons for the absence of individual physicians in the mediations. ${ }^{246}$ For some, it was their work schedule. ${ }^{247}$ For others, the attorneys did not want the doctors to be "verbally attacked by the plaintiff." ${ }^{248}$ There has also been research that although patients "expect an apology after a medical error," most doctors do not do apologize out of fear that it will lead to legal liability. ${ }^{249}$ If physicians attended the mediations, not only are they reducing their ability to learn from the mistakes and improve the quality of their care but the plaintiff may not be as satisfied with the process as they could have been had the physician been present ${ }^{250}$ Mediations are confidential and what is discussed is not admissible in court. ${ }^{251}$ This should lead the parties to be open and honest about the case and gives the physicians and health care networks the ability to learn from a mistake and make any changes they see could benefit the system in the future. ${ }^{252}$

While there are certainly benefits to mediation, it is difficult to assess how

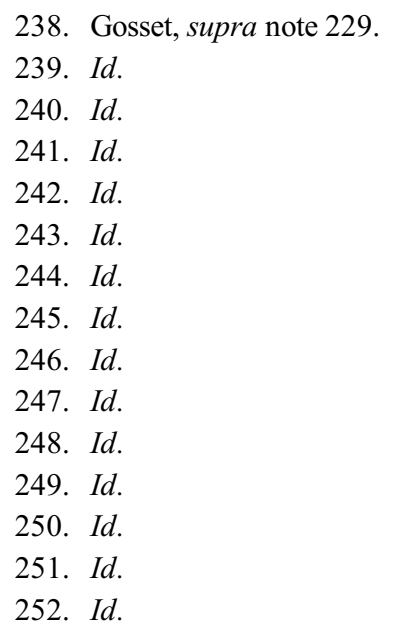


successful mediation can be. ${ }^{253}$ While cases may settle during mediation, cases also may settle after mediation as a result of the negotiations or conversations that occurred at mediation. ${ }^{254}$ Mediations have the potential to be very helpful in settling medical malpractice cases, but if that potential is not realized by the parties, it will be difficult to require everyone involved to agree to this resolution option.

\section{Intentional Delay Remedies}

A more efficient panel process would be created by enacting stringent deadlines and providing remedies to plaintiffs should the process go beyond those deadlines. Extreme time delays are caused when attorneys do not want deadlines enforced, and panel chairs are not consistently enforcing deadlines. ${ }^{255}$ Although the statute contains sufficient remedies for delay, if attorneys do not turn to the courts to enforce them, the remedies remain dormant. ${ }^{256}$ The attorneys in the chairman position are vested with the duties to "expedite the selection of the other panel members" and "expedite the panel's review of the proposed complaint."257 These responsibilities should include providing reasonable deadlines to the parties and making sure the deadlines are being met. Monetary sanctions could be imposed if the deadlines are not met. Alternatively, significant delays in the panel process could allow the plaintiff to proceed directly to court and bypass the rest of the panel process.

\section{Apology Statutes}

The high rate of medical malpractice claims can sometimes be caused by a strained or distant relationship between a patient and a doctor. ${ }^{258}$ In an effort to change this relationship, a majority of states, including Indiana, have enacted "apology statutes." 259 These statutes are aimed at reducing medical malpractice claims, liability, and litigation expenses. ${ }^{260}$ The hope is that an apology will reduce the patient's frustration and anger after feeling that their physician has not met the standard of care. A study found that physicians and hospital staff that are "willing to discuss, apologize for and resolve adverse medical events through a 'collaborative communication resolution program" experience a decrease in the

253. Nussbaum, supra note 11 , at 280-81.

254. Id.

255. Stafford, supra note 112.

256. Id.; see IND. CODE § 34-18-10-14 (2020).

257. IND. CODE § 34-18-10-3 (2020).

258. See Bowen, supra note 13.

259. Bonnie G. Ackerman, You Had Me at "I'm Sorry”: The Impact of Physicians' Apologies on Medical Malpractice Litigation, NAT'L L. REV. (Nov. 6, 2018), https://www.natlawreview. com/article/you-had-me-i-m-sorry-impact-physicians-apologies-medical-malpractice-litigation [https://perma.cc/M9K6-N6FV].

260. Id. 
number of legal claims filed against them, time spent on resolving cases, and litigation costs. ${ }^{261}$ The apology statute in Indiana provides that a court cannot admit into evidence "a communication of sympathy that relates to causing or contributing to: (1) a loss; (2) an injury; (3) pain; (4) suffering; (5) a death; or (6) damage to property." 262

While improved relationships and more transparency between physician and patient may reduce the number of malpractice claims, a fear that the apology may appear to be a statement of fault can prevent physicians from using the provisions in these statutes. ${ }^{263}$ Although this fear exists, studies have shown that apologies can reduce the cost of litigation while allowing physicians to exhibit their humanity and provide closure to patients and patients' family members. ${ }^{264}$ Even in states that already have apology statutes, it is important that health care providers are aware of the statute in their state and know the benefits that could come from a simple apology to "soothe the feelings of a patient or family" and keep a doctor-patient relationship strong. ${ }^{265}$

\section{CONCLUSION}

While the Supreme Court of Indiana has held that the Medical Malpractice Act is constitutional, the court's reliance on the premise of a reasonable delay to the courts could result in a challenge brought in the future. The delay to plaintiffs' access to the courts could be lessened if the overall time the panel process takes is reduced, thereby strengthening the likelihood that the Act will continue to be upheld as constitutional. The presence of a medical malpractice crisis in the country and the constitutionality of tort reform efforts may be divided politically, but attempts to make the process fair and timely should be an important goal for all parties involved.

Many tort reform efforts in place today result in at least some extra delay and cost in contrast to going straight to court. However, some options may be better than others. In Indiana, the extreme delay that is currently placed on plaintiffs' cases in the medical review panel process is a problem that should be addressed. If the deadlines in the Medical Malpractice Act pertaining to the medical review panels were enforced, the delay would be considerably lessened. This would require the panel chair to establish and enforce the deadlines, and attorneys should also be encouraged to turn to the courts for relief if a party is not complying. Alternatively, a new reform measure should be considered. Allowing

plaintiffs to avoid the medical review panel process with an affidavit of merit that would likely decrease the delay while also accomplishing the goal of reducing the number of frivolous claims. Although the Indiana Supreme Court has previously

261. Id.

262. IND. CODE $\S 34-43.5-1-4$ (2020).

263. Nicole Saitta \& Samuel D. Hodge, Jr., Efficacy of a Physician's Words of Empathy: An Overview of State Apology Laws, 112 J. Am. Osteopathic Ass'N 302, 302 (2012).

264. Id. at 303.

265. Id. at 306 . 

MEDICAL REVIEW PANEL PROCESS

ruled the panel process constitutional, there is a stark difference in the time of delay now compared to in the past, and the delay may not be considered reasonable anymore. Whether or not there is a malpractice crisis in the United States, a multi-year delay of access to the court system, a constitutional provision no less, is a problem worth reconsidering. 